Article

\title{
Prescribed Burn Effects on Natural Regeneration in Pine Flatwoods: Implications for Uneven-Aged Stand Conversion from a Florida Study
}

\author{
Ajay Sharma ${ }^{1, *}$, Daniel K. Brethauer ${ }^{1}$, Justin McKeithen ${ }^{1}$, Kimberly K. Bohn ${ }^{2}$ and \\ Jason G. Vogel ${ }^{3}$ \\ 1 West Florida Research and Education Center, University of Florida, Milton, FL 32583, USA; \\ brethauerd@ufl.edu (D.K.B.); justmck@ufl.edu (J.M.) \\ 2 Forest Technology, The Pennsylvania State University, Mont Alto, PA 17237, USA; kkb29@psu.edu \\ 3 School of Forest Resources and Conservation, University of Florida, Gainesville, FL 32611, USA; \\ jvogel@ufl.edu \\ * Correspondence: ajay.sharma@ufl.edu; Tel.: +1-850-983-7129
}

Received: 12 February 2020; Accepted: 12 March 2020; Published: 15 March 2020

\begin{abstract}
Uneven-aged silvicultural approaches are increasingly utilized as efficient management strategies for economic and ecological sustainability of forest resources, including in the southeastern United States where there is interest in converting intensively managed pine plantations to uneven-aged stands. However, success of stand conversion and perpetuation of an uneven-aged forest stand depends on obtaining adequate regeneration of the desired species and its ability to develop into merchantable size classes. In fire-maintained ecosystems, regeneration dynamics can be challenging for species such as slash pine that are not tolerant of fire in the seedling stage. In this study, we examined the survival of slash pine (Pinus elliottii Englm.) regeneration (seedlings and saplings) following prescribed burns in (1) a harvest-created gap (0.4 ha; $70 \mathrm{~m}$ diameter) and (2) a mature stand with abundant advanced regeneration at two mesic-hydric flatwoods sites in northwest Florida, USA. We characterized the prescribed burns at the two sites and quantified survival of regeneration of different size classes $(<1 \mathrm{~m}, 1-2 \mathrm{~m}, 2-3 \mathrm{~m},>3 \mathrm{~m})$ at 10 months after the burn. Within the gap, the greatest survival of regeneration was observed at the center (12.5\% survival) in comparison to the other positions in the gap (1.92\% to $7.14 \%$ survival), with all seedlings $<3 \mathrm{~m}$ height killed by the burn. In the stand with advance regeneration, survival ranged between $0 \%$ and $50 \%$ at different positions, with all regeneration smaller than $2 \mathrm{~m}$ killed by fire. Overall, we observed $6.36 \%$ and $23.2 \%$ survival in the harvest-created gap and the stand with advance regeneration, respectively. Despite these low percent survival values, post-burn slash pine regeneration (seedlings/saplings) density equaled 725 and 4800 per hectare, respectively. Our modeling projections suggest that this level of post-burn regeneration density may be adequate for stand conversion and sustainable uneven-aged silvicultural management of slash pine. These results suggest that seedling size is the preeminent control on slash pine survival after prescribed burn. However, long-term monitoring of stand dynamics following future prescribed burns and cutting cycle harvests will help confirm if slash pine can be sustainably managed using uneven-aged silviculture.
\end{abstract}

Keywords: southern pine; stand conversion; uneven-aged silviculture; group selection; regeneration; forest restoration; forest structure

\section{Introduction}

Uneven-aged silviculture is increasingly viewed as an appropriate forest management approach to optimize economic and ecological benefits obtained from forests [1-5]. In the southeastern United 
States, recent decades have witnessed increasing interest in managing and restoring southern pines species using uneven-aged silvicultural strategies, and simple even-aged plantation stands are being converted to complex uneven-aged structures that rely on natural regeneration [6-8]. The stand conversion strategies typically involve partial cutting of the stand-either uniformly over the stand or in gaps of different sizes-to allow the natural establishment of multiage cohorts and eventual application of uneven-aged silvicultural systems such as single tree selection or group selection [9-14]. Advance regeneration consisting of existing seedlings and saplings in a stand can also serve an important role in creating uneven-aged forests $[4,13,15]$. Advance regeneration trees have a height advantage and the conversion harvests may target gap creation in areas where advance regeneration is already present, thereby decreasing the likelihood that newly created gaps will become occupied by competing woody vegetation [16]. In either case, the success of such conversions and subsequent application of uneven-aged silviculture in forest stands fundamentally depends on obtaining adequate regeneration after a cutting cycle, which will develop into large size classes and overstory. Regeneration success, survival, and recruitment of pines depend on several factors, including the silvics of the tree species, stand density, site conditions, management, and prescribed fire [17-19].

While natural regeneration and uneven-aged silviculture of some southern pines, including longleaf pine (Pinus palustris Mill.) and loblolly (P. taeda L.)/shortleaf pines (P. echinata Mill.), have received considerable research effort [7], slash pine (P. elliottii Englm.) has largely been ignored. Yet in Florida, slash pine is the dominant species constituting 27\% of total forest area, much higher than the extent of longleaf pine (5.7\%) or loblolly pine $(6.5 \%)$ [8]. As a shade-intolerant species, slash pine occurs primarily in natural wet and hydric flatwoods sites with species-rich understory and contributes to the habitat of a large variety of faunal species $[20,21]$. While slash pine is currently managed for timber production in intensive plantations, uneven-aged management of complex slash pine flatwoods ecosystems may offer an alternative to meet diverse objectives including timber production, biodiversity enhancement, habitat conservation, recreation, and carbon sequestration [22]. However, our experience with natural regeneration-dependent uneven-aged silviculture in slash pine is very limited.

Wet flatwoods may pose additional challenges to the application of uneven-aged silviculture due to their unique hydric, patchy shrubby conditions, and their effects on fire ecology and regeneration response. While the species produces profuse amounts of germinants and small seedlings immediately following regeneration cuttings [23], the real challenge is to ensure long-term survival of seedlings in wet, shrubby conditions and following prescribed burns. Slash pine flatwoods, like other southern pines, typically are prescribe burned periodically (two to four year burn cycles) to reduce fuel load, check shrub competition that adversely affects tree growth, and to maintain or enhance groundcover diversity [24-27]. If not burned, slash pine flatwoods succeed to southern mixed hardwood forests or bayheads [28]. Slash pine is tolerant of saturated to inundated soil conditions but not tolerant of fire as a small seedling, though saplings become more resistant as they mature, grow in tree height, and the bark thickens [17,29-32]. How the prescribed fire and slash pine survival dynamics will play out in a stand with a mature overstory and abundant regeneration of varying sizes is largely unknown, especially in situations when the forest management objective is to transform mature plantations to uneven-aged stand conditions.

We conducted this study in mature slash pine plantation stands at two different locations in northwest Florida to examine the fire tolerance of slash pine regeneration. One location had mature slash pine plantation stands under active conversion to uneven-aged stands. The other location had mature slash pine plantation stands with abundant advance regeneration which could provide an advantage to stand conversion process. The objectives were (a) to characterize prescribed fire environment in slash pine stands with the presence of abundant regeneration and (b) assess slash pine regeneration response to prescribed fire. We quantified slash pine regeneration survival after 10 months of prescribed fire and determined the critical regeneration size above which slash pine is more likely to survive prescribed fire. We used a network of temperature sensors and data loggers installed in slash 
pine stands to make measurements of fire intensity and inventoried pre- and post-burn regenerations (seedlings and saplings).

\section{Materials and Methods}

\subsection{Study Area and Treatments' History}

The two study locations, viz., (1) Tate's Hell State Forest (29.93 N, 84.77 W) (hereafter referred to as "Tate's Hell") and (2) Ward Basin Tract (30.59 N, 86.96 W) of the Yellow River Water Management Area (hereafter referred to as "Ward Basin") are mesic-wet flatwoods sites in northwest Florida (Figure 1).

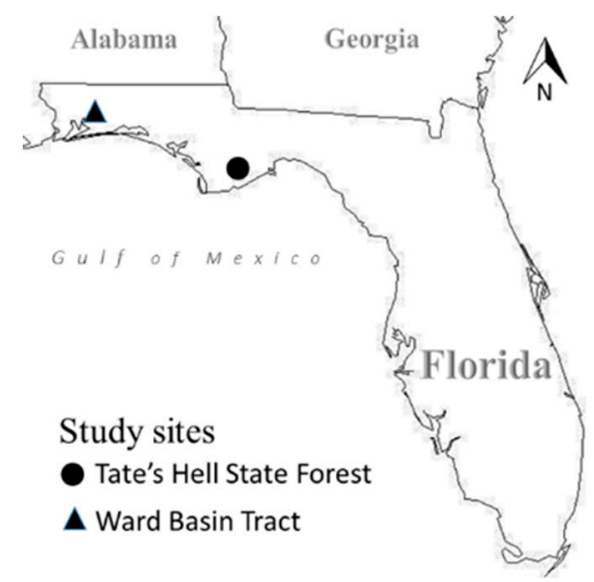

Figure 1. Location of study sites (Tate's Hell State Forest and Ward Basin Tract) in northwest Florida, USA.

Tate's Hell consisted of mature slash pine plantation stand under active conversion to an uneven-aged stand structure using the group selection harvest approach. Group harvests were conducted in December 2011 and the area burned in 2015 and again (for this study) in March 2018. The site and the uneven-aged conversion harvest treatments at Tate's Hell have been described in detail in Sharma et al. [8]. For this part of the study, we considered a circular gap of size 0.4 ha ( 70 m diameter). The gap had profuse slash pine regeneration varying in size from less than $1 \mathrm{~m}$ to more than $3 \mathrm{~m}$ height. Ward Basin, the other site, consisted of approximately 540 ha of mature slash pine plantations. The stands were established in 1994-1995 and were never thinned or burned prior to this study (March 2018). The stand had an average basal area of approximately $12 \mathrm{~m}^{2} \mathrm{ha}^{-1}$, with abundant advance regeneration of varying sizes present at several locations. In addition to a mature pine canopy and young regeneration, these wet flatwood site conditions were characterized by the irregular and patchy presence of shrubs across the stands.

The land management goal at the study locations is to restore plantations to native pine ecosystems with a structurally diverse overstory and species-rich understory, as well as to integrate public use and recreation. This is being considered by implementing partial harvesting of the stands to encourage natural regeneration and/or release advance regeneration, leading to the development of uneven-aged stand structure. Prescribed burning is being introduced at a frequency of every two to four years to promote pine regeneration and enhance understory species diversity.

\subsection{Experimental Setup, Regeneration Sampling and Prescribed Burning}

At each study location, we established multiple $5 \mathrm{~m} \times 5 \mathrm{~m}$ measurement plots and measured heights of all regeneration (seedlings/saplings) in them. We classified the regeneration into height classes of (a) $<1 \mathrm{~m}$ ), (b) 1-2 m, (c) 2-3 m, and (d) $>3 \mathrm{~m}$. In Tate's Hell, a total of five plots were established in a 0.4 ha ( $\sim 70 \mathrm{~m}$ diameter) circular gap at the northern and southern positions, in the gap 
center, and in between the northern and southern positions and center at equal intervals of $17.5 \mathrm{~m}$ (see Figure 2). In Ward Basin, four plots were established in the mature stand.

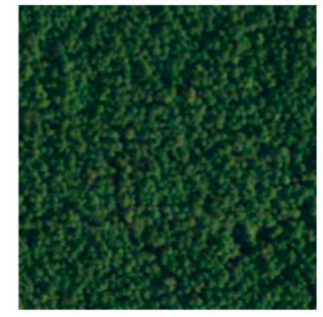

2011 (Preharvest)

(a)

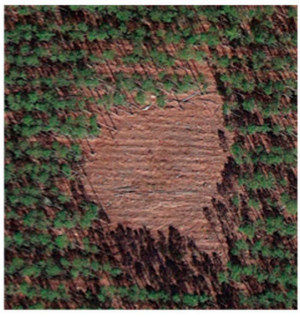

2012 (Postharvest)

(b)

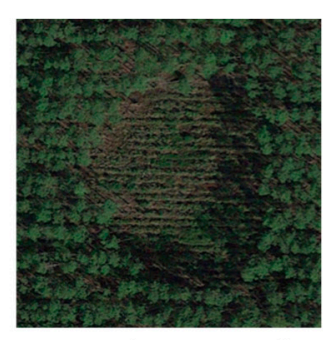

2018 (Burn year)

(c)

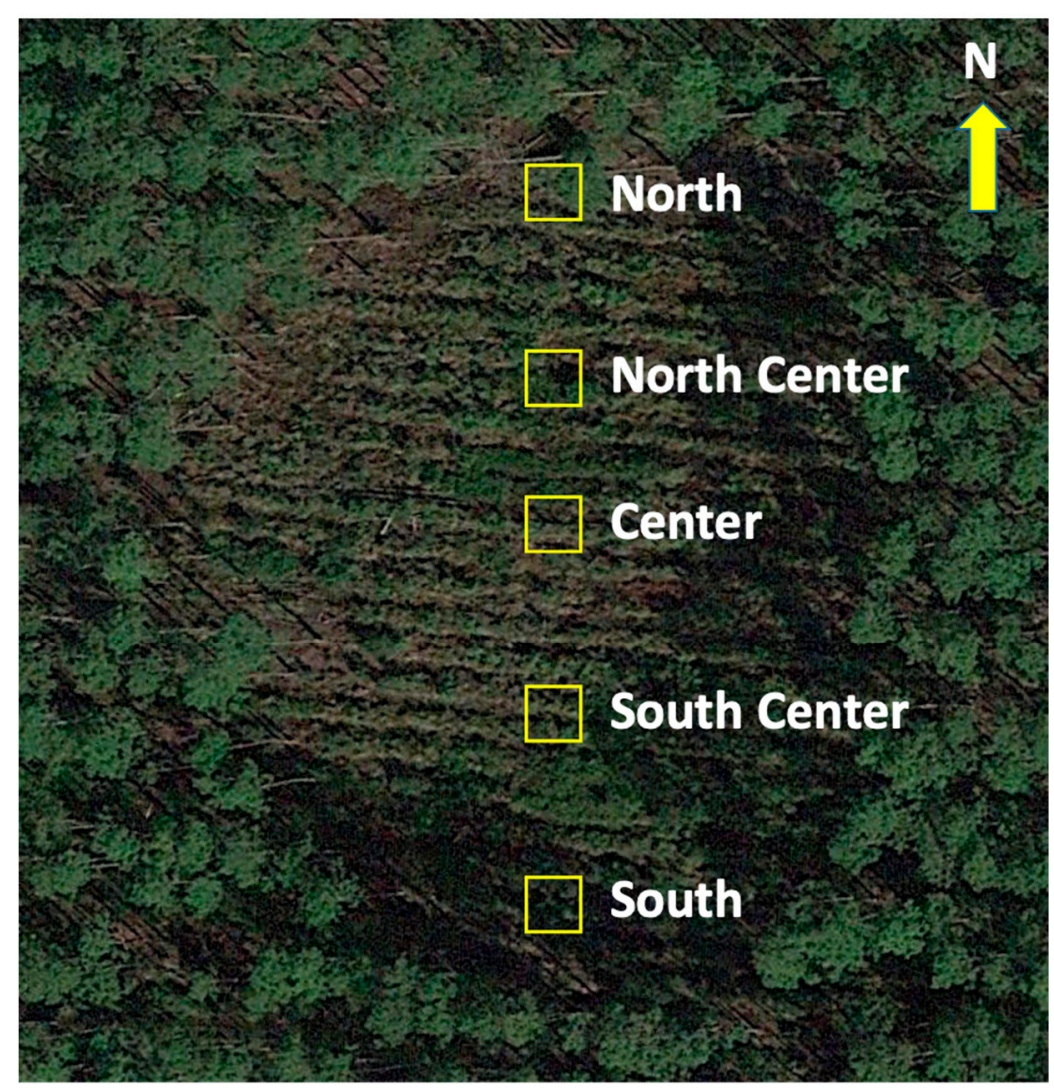

Enlarged 2018 showing layout of measurement plots

(d)

Figure 2. Stand history $(\mathbf{a}-\mathbf{c})$ and measurement plot positions (d) at the Tate's Hell site. Group selection harvest was conducted in December 2011 and the study area was burned in March 2018.

Within each of these plots, at systematic positions at four corners and center, we installed steel poles and set up thermocouple sensors (K-type thermocouples, Omega Engineering, Inc.) at $0 \mathrm{~cm}$ (ground level), $66 \mathrm{~cm}, 132 \mathrm{~cm}$, and $200 \mathrm{~cm}$ on each pole (Supplementary Figure S1). These thermocouples were connected to dataloggers (HOBO UX120 Thermocouple Data Logger, Onset Computer Corporation) sealed in waterproof cases and buried in soil to avoid fire damage. Near to each plot in an area similar to the plot we collected fine fuel from a $1 \mathrm{~m}^{2}$ quadrat. We recorded the fresh weight of fuel material in the field and transported the fuel to the lab in sealed bags. We then dried the fuel material in drying ovens for $48 \mathrm{~h}$ and recorded dry weights. 
The Tate's Hell site was burned entirely using ground ignition techniques utilizing backing and flanking fires, that provided a consistent fire intensity across the burn area. The Ward Basin site was burned using ground and aerial ignition techniques. Here, ground ignition was used to ignite the backing and flanking fires while aerial ignition lit a grid of spot fires. This burning technique is typical in the southeastern United States for large prescribed burns ( $>400$ ha), particularly where ground access may be limited. The fire effects from these fires are variable fire intensity and fuel consumption with occasional hotspots that can scorch and/or cause mortality in the overstory.

The day after the burn, we assessed seedling condition (crown and stem scorch, and foliar consumption) and recollected the thermocouples from the study plots and downloaded the recorded data from dataloggers to our computers. We revisited the plots periodically over the next 10 months to monitor the burned plots and identify and count the surviving regeneration. (Supplementary Figure S2 shows the plot conditions over a period of 10-months.) Using the pre-burn regeneration data and the post-burn (10-month) regeneration data, we calculated percent regeneration survivals for different regeneration size classes at the two sites.

\subsection{Data Description and Processing}

Data from the thermocouples consisted of temperature values recorded at 10 -s intervals. From these data we constructed temperature variation curves averaged over 1-hr intervals to characterize temperature fluctuations over a typical day at the site, as well as the temperature fluctuation on the day of burn. For the burn day, we also calculated mean temperature exposure (MTE). MTE was obtained as the cumulative temperatures above $60^{\circ} \mathrm{C}$ recorded by the thermocouples for the duration temperatures were above $60^{\circ} \mathrm{C}$ [33]. Seedling crown and stem scorch and foliar consumption percentages were calculated as means for all plots. The values of regeneration density pre- and post-burn were converted to per hectare values for all plots. Survival percent of regeneration was calculated as (post-burn regeneration densities/pre-burn regeneration density) ${ }^{*} 100$.

\section{Results and Discussion}

\subsection{Prescribed Burn and Regeneration Responses in Group Selection Harvest}

\subsubsection{Fuel Distribution}

Fine fuel load was higher at the northern and southern positions than in the center of the gap (Table 1). This is a common observation as northern and southern positions receive more needles from border trees [19,34-39]. The fresh fuel load at northern and southern positions was 0.94 to $1.48 \mathrm{~kg} / \mathrm{m}^{2}$, while dry weight was 0.82 to $1.11 \mathrm{~kg} / \mathrm{m}^{2}$, respectively. Not surprisingly, the gap center had the lowest amount of fine fuel load (Fresh weight $=0.75 \mathrm{~kg} / \mathrm{m}^{2}$; Dry weight $=0.62 \mathrm{~kg} / \mathrm{m}^{2}$ ).

Table 1. Fine fuel load distribution across positions in the harvest created gap in a slash pine plantation.

\begin{tabular}{|c|c|c|}
\hline Position in Gap & Fresh Weight $\left(\mathrm{kg} / \mathrm{m}^{2}\right)$ & Dry Weight $\left(\mathrm{kg} / \mathrm{m}^{2}\right)$ \\
\hline North & 0.94 & 0.82 \\
\hline North Center & 0.94 & 0.70 \\
\hline Center & 0.75 & 0.62 \\
\hline South Center & 0.55 & 0.45 \\
\hline South & 1.48 & 1.11 \\
\hline
\end{tabular}

\subsubsection{Temperature and Burn Characteristics}

As expected, air temperatures followed a predictable diurnal pattern. The air temperature was low at midnight and decreased until sunrise, after which it increased steadily, reached a maximum at around noon to early afternoon and decreased afterwards (Figure 3A). Temperature, like understory light, is not distributed equally in gaps, with variation caused by latitude, the size of gaps, and the 
height of the gap border trees [40-42]. While the overall diurnal pattern of temperature was similar at different positions in the gap, the temperature was highest and reached its maximum earlier (at noon) at the northern position of the gap and was lowest and reached maximum later in the afternoon at the southern position of the gap.

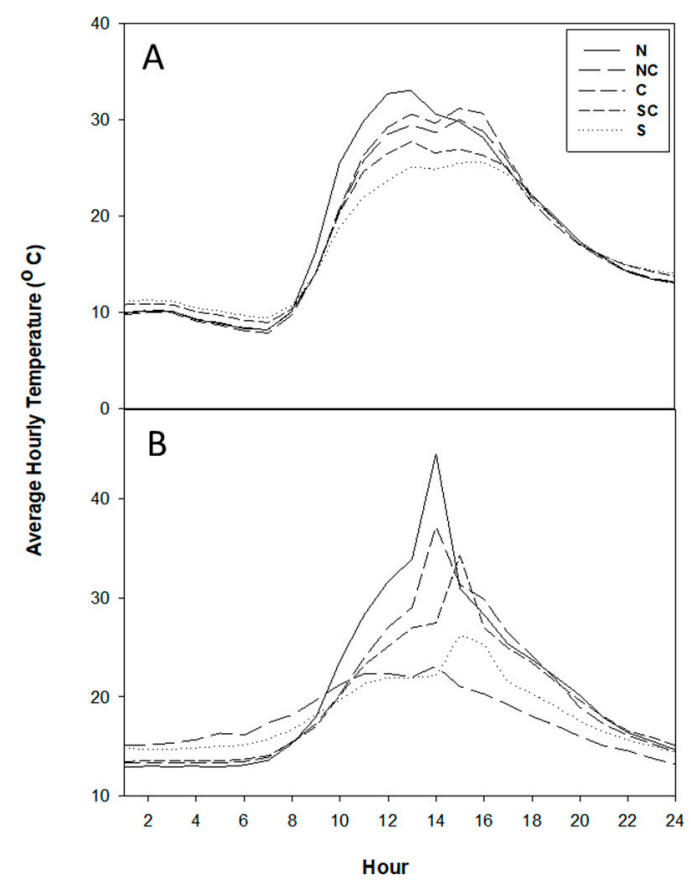

Figure 3. Temperature (averaged hourly) dynamics over $24 \mathrm{~h}$ of a day in gap positions, recorded 10 days before the burn day (A) and on the day of burn (B). Zero (0) hour represents 12 am (midnight). Positions are north(N), North Center (NC), Center (C), South Center (SC), and South (S).

The higher levels of temperature in the northern side of the gap compared to the southern side of the gap in our study are likely due to the study site's location being in the Northern Hemisphere where the sun angle is lower than at the equator [40]. In the Northern Hemisphere, the northern-center side of a gap receives sunlight in the highest amount as well as earlier in the morning than southern side. We found a similar pattern in light availability in our other study on the same site [8].

During the prescribed burn the different gap positions did not burn at the same intensity (Figure 3B). Vertically, we observed that, in general, the temperature conditions were more intense at ground level than at the higher points (Figure 4). In most cases, MTE was the highest at the ground level and least at $2 \mathrm{~m}$ height from the forest floor. MTE was also more variable at the forest floor level than at the higher levels.

These horizontally and vertically variable intense burns create environmental heterogeneity that may play a role in regulating structural and groundcover diversity in the pine ecosystems of the southeastern United States $[35,39,43,44]$. The vertical attenuation of MTE also indicates that as a whole the smaller seedlings are subjected to higher temperatures than the larger seedlings. This high temperature combined with the seedlings' juvenility possibly make seedlings of smaller size classes more susceptible to kill in the prescribed fires [19,31,32,45,46].

MTE did not appear to correlate with fine fuel load. This was possibly because the flatwoods study sites have highly variable microclimatic and microtopographic conditions, with the remnant bedding and highly variable wetness in the gaps, that affected fuel ignition as well as the fuel combustibility and fire temperatures at different positions [47]. Additionally, we measured only fine fuel loads, while the irregularly scattered shrub covers in the gap also provided the fuel. This varying intensity of the burn across the gap possibly was also responsible for the differences in the seedling survival observed in the study (described below). Robertson et al. [44] made similar observations in longleaf pine savannas. 


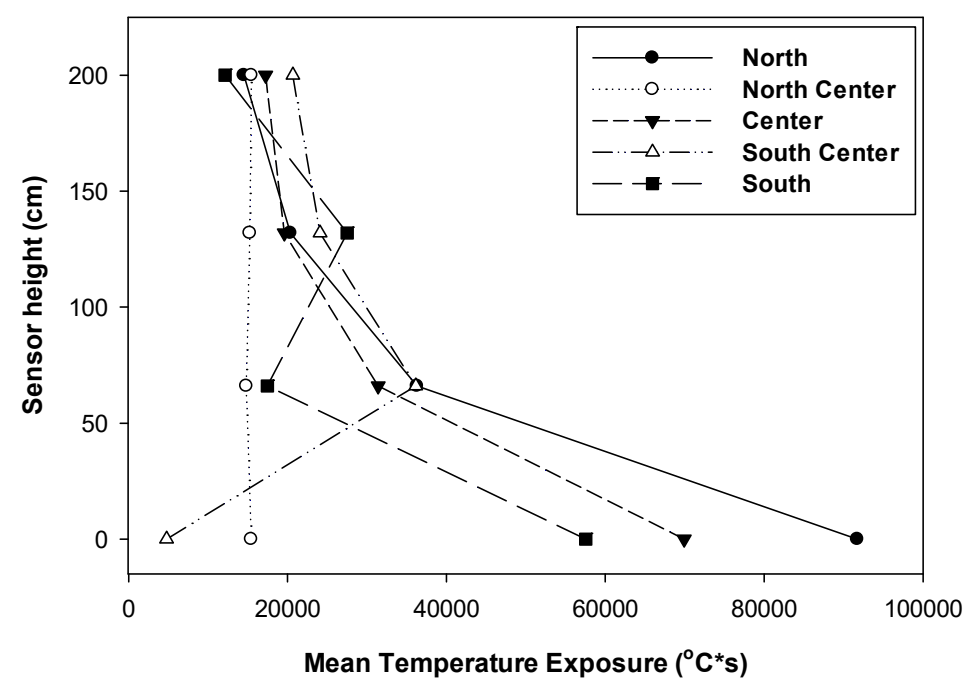

Figure 4. Gap position and vertical distribution of mean temperature exposure (MTE) at different positions in the group selection harvest in slash pine.

\subsubsection{Regeneration Responses}

Prior to the burn, the north side of the gap had higher total numbers but smaller sizes of regeneration than other positions (center positions) in the gap. The southern position of the gap had the least amount of regeneration, and the regeneration was smaller than the center as well. The gap center had the largest-sized regeneration but in lower numbers than the northern or southern positions (Figure 5). Several other studies on southern pines have reported similar regeneration responses in gaps [34,42,48]. Gap centers potentially receive less seed from the seed trees [16] and usually are free from competition from the border trees $[34,42,48]$. Additionally, the gap centers receive plenty of sunlight $[8,41,42]$. In combination, these factors lead to fewer but more vigorous and larger pine regeneration in the gap center. The north position of the gap receives abundant sunlight but also faces competition from the bordering trees. The southern position receives the least amount of sunlight and faces competition from the border trees as well, leading to smaller and fewer pine than elsewhere in the gap.

Burning caused variable amounts of seedling crown and stem scorch and foliar consumption (Table S1). All regeneration smaller than $3 \mathrm{~m}$ died 10 months following the burn, irrespective of their position in the gap or MTE (Figure 5). Approximately $69 \%$ of regeneration greater than $3 \mathrm{~m}$ survived. The highest survival of regeneration (12.5\%) was observed in the center of the gap, primarily because the gap center had the highest number and proportion of large-sized $(>3 \mathrm{~m})$ regeneration. Understandably, as seedlings age, they grow in height, increase bark thickness and become structurally strong and more fire resistant than younger or smaller seedlings [31,49-51]. Conversely, smaller pine seedlings also led to a decrease in the number of surviving regeneration from the center to the north or south of the gap (Figure 5). Overall, across the gap after 10 months of prescribed burning, only $6.36 \%$ (725 stems/ha) of all regeneration survived. This seedling density and size distribution in a gap results from resource availability (aboveground and belowground) and its interaction with prescribed fire over the year, possibly leading to the characteristic dome shape of sapling size distribution from the northern or southern positions to the center of gaps [19,34]. 


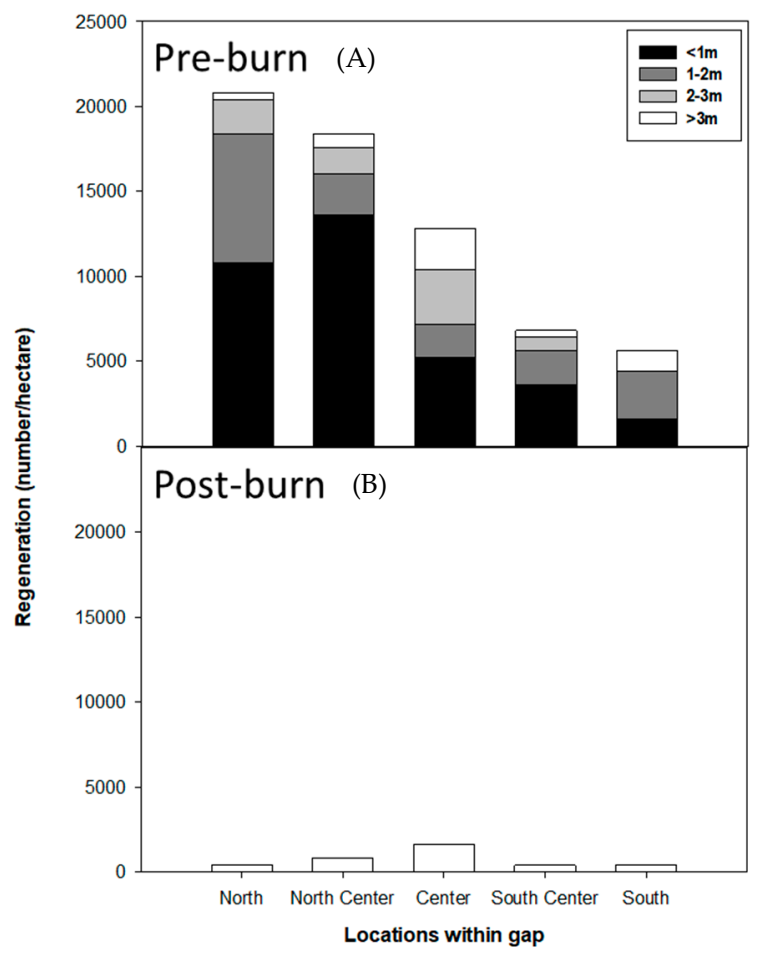

Figure 5. Pre-burn (A) and 10-month post-burn (B) regeneration size and number distribution at different gap positions in a group selection harvest in slash pine. Only regeneration $>3 \mathrm{~m}$ survived 10 months after the burn.

\subsection{Prescribed Burn and Regeneration Responses in Mature Stand with Advance Regeneration}

\subsubsection{Fuel Distribution}

Fine fuel load in these unburned slash pine stands with advanced regeneration was highly variable. The fresh weight of fine fuels ranged between 0.87 to $4.3 \mathrm{~kg} / \mathrm{m}^{2}$. Dry weight was less variable and ranged between 0.65 and $1.9 \mathrm{~kg} / \mathrm{m}^{2}$ (Table 2). This is not surprising given that the site is mesic-wet flatwoods with patches of standing water across the stand where some of the plots were located.

Table 2. Fine fuel loads in different plots with advance regeneration in a slash pine plantation.

\begin{tabular}{|c|c|c|}
\hline Plot Number & Fresh Weight $\left(\mathrm{kg} / \mathrm{m}^{2}\right)$ & Dry Weight $\left(\mathrm{kg} / \mathrm{m}^{2}\right)$ \\
\hline 1 & 0.87 & 0.67 \\
\hline 2 & 1.62 & 0.99 \\
\hline 3 & 4.3 & 1.9 \\
\hline 4 & 1.48 & 0.65 \\
\hline
\end{tabular}

\subsubsection{Temperature and Burn Characteristics}

The measurement plots showed typical temperature fluctuation over a day (Figure 6A). Like at the Tate's Hell site, different plots did not burn at the same temperature (Figure 6B). However, the burn environment at this study site was less variable and more consistent as compared to the group selection harvest experiment.

Again, we observed at this site the general trend that the temperature conditions were more intense at the ground level and moderated with height (Figure 7). In all the cases, the MTE was highest at the ground level and least at $2 \mathrm{~m}$ height. As in group selection harvest, there was greater variability in MTE at the forest floor level and it decreased with height. As in the other study site, MTE did not appear to relate with the fuel load. 


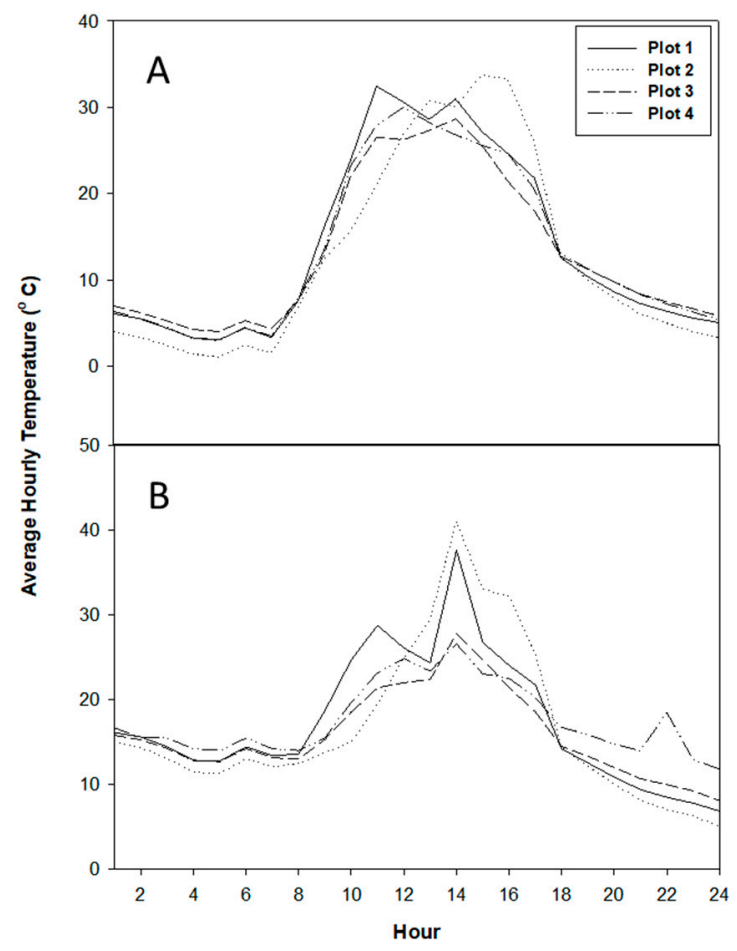

Figure 6. Temperature (averaged hourly) dynamics over $24 \mathrm{~h}$ of a day in the plots, recorded 10 days before the burn day (A) and on the day of burn (B).

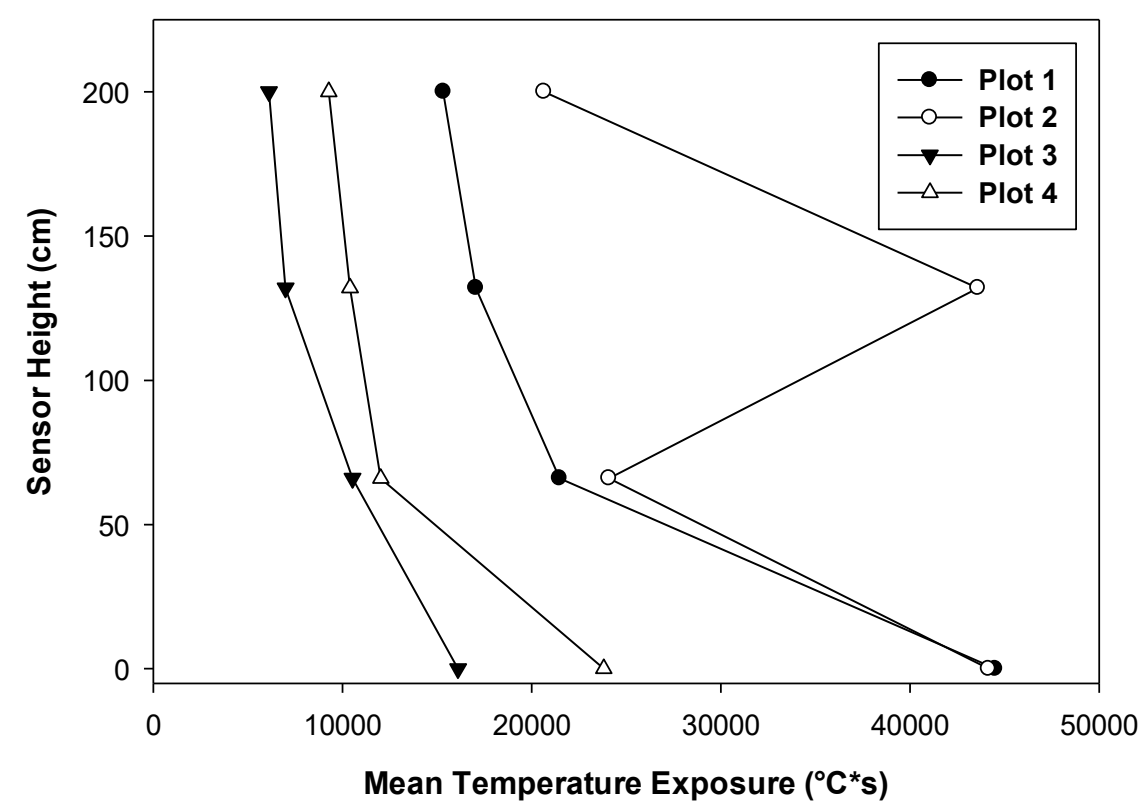

Figure 7. Horizontal and vertical distribution of mean temperature exposure (MTE) in different plots with advance regeneration.

\subsubsection{Regeneration Responses}

Prior to the burn, advance regeneration density varied between 4800 to 12,400 per hectare across the measurement plots. As in Tate's Hell, burning at this site caused variable amounts of seedling crown and stem scorch and foliar consumption in the plots (Table S2). At this site, 10 months following the burn, all seedlings smaller than $2 \mathrm{~m}$ died, irrespective of the MTE of the plots (Table 3). Fifty \% of seedlings between $2-3 \mathrm{~m}$ survived, while seedlings greater than $3 \mathrm{~m}$ had 100\% survival. Overall, across 
the plots, $23.2 \%$ (4800 stems/ha) of all advance regeneration survived prescribed fire after 10 months. Greater survival of regeneration in this site compared to Tate's Hell is likely due to the lower MTE experienced by this site, which was nearly half of that of the Tate's Hell site for most of the plots. Greater temperature during a fire generally causes greater decline in plant physiological function and growth and an increase in seedling mortality [31].

Table 3. Advance regeneration (pre-burn/10-month post-burn) per hectare following prescribed fire in a slash pine flatwoods.

\begin{tabular}{llllll}
\hline Plot Number & \multicolumn{2}{l}{ Regeneration Size Class (m) } & \multicolumn{2}{l}{ \% Survival (Plot) } \\
& $<\mathbf{1}$ & $\mathbf{1 - 2}$ & $\mathbf{2 - 3}$ & $\mathbf{3}$ & \\
\hline 1 & $10000 / 0$ & $1600 / 0$ & $800 / 0$ & $\mathrm{n} / \mathrm{a}$ & 0 \\
2 & $6000 / 0$ & $1600 / 0$ & $\mathrm{n} / \mathrm{a}$ & $\mathrm{n} / \mathrm{a}$ & 0 \\
3 & $400 / 0$ & $1600 / 0$ & $1200 / 800$ & $1600 / 1600$ & 50 \\
4 & $800 / 0$ & $2000 / 0$ & $1200 / 800$ & $1600 / 1600$ & 42.8 \\
\hline$\%$ Survival (size class) & 0 & 0 & 50 & 100 & $23.2=$ Overall \% survival \\
\hline \multicolumn{7}{l}{ * n/a means not applicable; seedlings of the given size were not present. }
\end{tabular}

\subsection{Implications for Stand Conversion}

Successful reproduction of the desired species and its ability to develop into merchantable size classes is essential to convert and perpetuate an uneven-aged forest stand [13,52]. If an even-aged stand is unable to add another age class following regeneration harvests, stand conversion and eventual application of uneven-aged silviculture becomes infeasible [16,52].

Despite the high rate of mortality following prescribed burns, the post-burn regeneration densities of 725 and 4800 stems per hectare in the group selection harvest and the stand with advance regeneration, respectively, may be adequate to sustain slash pine uneven-aged stands. We earlier found-using simulation modeling - that uneven-aged silvicultural management for these forest ecosystems can be sustainable if the surviving regeneration consisted of 247 or more seedlings per hectare following the regeneration cuttings [53]. Such a level of regeneration survival following 10 to 20-year cutting cycles may lead to sustained timber production, stand carbon, as well as maintain high structural diversity in slash pine stands $[22,53]$. This level of regeneration could also allow some losses from logging when stands with advance regeneration are harvested with losses varying depending on the harvest method, season, and volume of trees removed. If a future cutting cycle fails to secure a new age class of regeneration, Guldin and Baker [54] suggest that supplemental site preparation efforts should be made in the next cutting cycle harvest to ensure that regeneration is obtained.

\section{Conclusions}

Slash pine seedlings are highly prone to kill by prescribed fire, more so when they are small. Regeneration shorter than $2 \mathrm{~m}$ invariably dies following prescribed fire, irrespective of fire intensity. Advance regeneration above $2 \mathrm{~m}$ size in mature slash pine plantation has a fair chance of surviving the prescribed fire and may eventually add a second age class to the stand during conversion. In a group selection harvest, however, the seedling survival dynamics is more complex and is variable across the gaps. Regeneration smaller than $3 \mathrm{~m}$ is unlikely to survive prescribed fire in this case, given the intensity of burn observed in our study. Most of the surviving regeneration is concentrated at the gap center. For the successful transition of a slash pine stand from even- to uneven-aged structure, we suggest that prescribed burning be delayed until an adequate amount of regeneration larger than $3 \mathrm{~m}$ is present. The level of surviving regeneration following prescribed fire in our study indicates the feasibility of sustainable application of uneven-aged silviculture in slash pine flatwoods ecosystems, though more severe fires than observed in our study could be a cause of concern. Long-term monitoring of stand dynamics following future prescribed burns and cutting cycle harvests, however, will help confirm if slash pine can be sustainably managed using uneven-aged silviculture. 
Supplementary Materials: The following are available online at http://www.mdpi.com/1999-4907/11/3/328/s1, Figure S1: Thermocouples setup at four heights $(0,67,134,200 \mathrm{~cm})$ on each of the five steel poles at systematic positions on four corners and center of a $5 \times 5 \mathrm{~m}$ measurement plot, Figure S2: Pre- and post-burn conditions in a group selection harvest plot at Tate's Hell State Forest, FL, USA., Table S1: Mean crown scorch, stem scorch, and foliar consumption (FC) percentages of slash pine regeneration in different gap positions after a prescribed burn in a group selection harvest in slash pine, Table S2: Mean crown scorch, stem scorch, and foliar consumption (FC) percentages of slash pine advance regeneration after a prescribed burn in mature slash pine stands.

Author Contributions: Conceptualization, A.S., K.K.B., J.M., D.K.B., and J.G.V.; methodology, A.S., D.K.B., and J.M.; formal analysis, A.S. and D.K.B.; investigation, A.S., J.M., and D.K.B.; resources, A.S. and K.K.B.; data curation, J.M. and D.K.B.; writing-original draft preparation, A.S.; writing-review and editing, K.K.B., J.G.V., D.K.B., and J.M.; supervision, A.S.; project administration, A.S., K.K.B., and J.G.V.; funding acquisition, A.S. All authors have read and agreed to the published version of the manuscript..

Funding: This research was funded by the USDA NIFA McIntire Stennis project \#1014653.

Acknowledgments: We acknowledge the support of The University of Florida IFAS CALS Summer Internship Program and The Federal Work-Study Program for supporting Daniel Brethauer. Special thanks are given to the Florida Forest Service and The Northwest Florida Water Management District for the opportunity to utilize the state forest lands and the logistical support.

Conflicts of Interest: The authors declare no conflict of interest. The funders had no role in the design of the study; in the collection, analyses, or interpretation of data; in the writing of the manuscript, or in the decision to publish the results".

\section{References}

1. Tahvonen, O.; Pukkala, T.; Laiho, O.; Lähde, E.; Niinimäki, S. Optimal Management of Uneven-Aged Norway Spruce Stands. For. Ecol. Manag. 2010, 260, 106-115. [CrossRef]

2. Diaci, J.; Kerr, G.; O’Hara, K. Twenty-first century forestry: Integrating ecologically based, uneven-aged silviculture with increased demands on forests. Forestry 2011, 84, 463-465. [CrossRef]

3. Nolet, P.; Kneeshaw, D.; Messier, C.; Béland, M. Comparing the Effects of Even-and Uneven-aged Silviculture on Ecological Diversity and Processes: A Review. Ecol. Evol. 2018, 8, 1217-1226. [CrossRef] [PubMed]

4. O'Hara, K.L. Multiaged Silviculture: Managing for Complex Forest Stand Structures; Oxford University Press: Oxford, UK, 2014.

5. Pukkala, T. Which Type of Forest Management Provides most Ecosystem Services? For. Ecosyst. 2016,3 , 9. [CrossRef]

6. Brockway, D.G.; Outcalt, K.W. Influence of Selection Systems and Shelterwood Methods on Understory Plant Communities of Longleaf Pine Forests in Flatwoods and Uplands. For. Ecol. Manag. 2015, 357, $138-150$. [CrossRef]

7. Guldin, J.M. Experience with the Selection Method in Pine Stands in the Southern United States, with Implications for Future Application. Forestry 2011, 84, 539-546. [CrossRef]

8. Sharma, A.; Bohn, K.K.; McKeithen, J.; Singh, A. Effects of Conversion Harvests on Light Regimes in a Southern Pine Ecosystem in Transition from Intensively Managed Plantations to Uneven-Aged Stands. For. Ecol. Manag. 2019, 432, 140-149. [CrossRef]

9. Brockway, D.G.; Outcalt, K.W. Influence of Reproduction Cutting Methods on Structure, Growth and Regeneration of Longleaf Pine Forests in Flatwoods and Uplands. For. Ecol. Manag. 2017, 389, $249-259$. [CrossRef]

10. Guldin, J.M.; Farrar, R.M. The Plantation Conversion Demonstration at the Crossett Experimental Forest-Implications for Converting Stands from Even-Aged to Uneven-Aged Structure. Gen. Tech. Rep. SRS-48; US Department of Agriculture, Forest Service, Southern Research Station: Asheville, NC, USA, 2002; pp. 281-286.

11. Kerr, G.; Morgan, G.; Blyth, J.; Stokes, V. Transformation from Even-Aged Plantations to an Irregular Forest: The World's Longest Running Trial Area at Glentress, Scotland. Forestry 2010, 83, 329-344. [CrossRef]

12. Loewenstein, E.F. Conversion of Uniform Broadleaved Stands to an Uneven-Aged Structure. For. Ecol. Manag. 2005, 215, 103-112. [CrossRef]

13. Nyland, R.D. Even-to Uneven-Aged: The Challenges of Conversion. For. Ecol. Manag. 2003, 172, $291-300$. [CrossRef] 
14. O'Hara, K.L. The Silviculture of Transformation-A Commentary. For. Ecol. Manag. 2001, 151, 81-86. [CrossRef]

15. Page, L.M.; Cameron, A.D.; Clarke, G.C. Influence of Overstorey Basal Area on Density and Growth of Advance Regeneration of Sitka Spruce in Variably Thinned Stands. For. Ecol. Manag. 2001, 151, 25-35. [CrossRef]

16. Brockway, D.G.; Outcalt, K.W.; Boyer, W.D. Longleaf pine regeneration ecology and methods. In The Longleaf Pine Ecosystem; Springer: Berlin, Germany, 2007; pp. 95-133.

17. Menges, E.S.; Deyrup, M.A. Postfire Survival in South Florida Slash Pine: Interacting Effects of Fire Intensity, Fire Season, Vegetation, Burn Size, and Bark Beetles. Int. J. Wildland Fire 2001, 10, 53-63. [CrossRef]

18. Sagra, J.; Moya, D.; Plaza-Álvarez, P.A.; Lucas-Borja, M.E.; González-Romero, J.; De las Heras, J.; Alfaro-Sánchez, R.; Ferrandis, P. Prescribed Fire Effects on Early Recruitment of Mediterranean Pine Species Depend on Fire Exposure and Seed Provenance. For. Ecol. Manag. 2019, 441, 253-261. [CrossRef]

19. Jack, S.B.; Pecot, S.D. Regeneration Dynamics, Competition, and Seedling Response. In Ecological Restoration and Management of Longleaf Pine Forests; CRC Press: Boca Raton, FL, USA, 2017; pp. 71-88.

20. Florida Natural Areas Inventory (FNAI). Guide to the Natural Communities of Florida, 2010 ed.; Florida Natural Areas Inventory: Tallahassee, FL, USA, 2010.

21. Sharma, A.; Bohn, K.K.; Jose, S.; Miller, D.L. Seed Bank-Vegetation Dynamics along a Restoration Management Gradient in Pine Flatwoods Ecosystems of the Florida Gulf Coast. Nat. Areas J. 2018, 38, $26-43$. [CrossRef]

22. Sharma, A.; Bohn, K.K.; Jose, S.; Dwivedi, P. Even-Aged vs. Uneven-Aged Silviculture: Implications for Multifunctional Management of Southern Pine Ecosystems. Forests 2016, 7, 86. [CrossRef]

23. Bohn, K.; Sharma, A. Slash Pine Regeneration and Groundcover Responses Following Harvesting in Hydric Flatwoods. In Proceedings of the 18th Biennial Southern Silvicultural Research Conference. E-Gen. Tech. Rep. SRS-212, Knoxville, TN, USA, 2 March 2015; US Department of Agriculture, Forest Service, Southern Research Station: Asheville, NC, USA, 2016; pp. 140-145.

24. Huffman, J.M.; Platt, W.J. Fire History of a Barrier Island Slash Pine (Pinus Elliottii) Savanna. Nat. Areas J. 2004, 24, 258-268.

25. Johansen, R.W. Prescribed Burning may Enhance Growth of Young Slash Pine. J. For. 1975, 73, $148-149$.

26. Cronan, J.B.; Wright, C.S.; Petrova, M. Effects of Dormant and Growing Season Burning on Surface Fuels and Potential Fire Behavior in Northern Florida Longleaf Pine (Pinus Palustris) Flatwoods. For. Ecol. Manag. 2015, 354, 318-333. [CrossRef]

27. Glitzenstein, J.S.; Streng, D.R.; Masters, R.E.; Robertson, K.M.; Hermann, S.M. Fire-Frequency Effects on Vegetation in North Florida Pinelands: Another Look at the Long-Term Stoddard Fire Research Plots at Tall Timbers Research Station. For. Ecol. Manag. 2012, 264, 197-209. [CrossRef]

28. Monk, C.D. Successional and Environmental Relationships of the Forest Vegetation of North Central Florida. Am. Midl. Nat. 1968, 79, 441-457. [CrossRef]

29. Sah, J.P.; Ross, M.S.; Snyder, J.R.; Ogurcak, D.E. Tree Mortality Following Prescribed Fire and a Storm Surge Event in Slash Pine (Pinus Elliottii Var. Densa) Forests in the Florida Keys, USA. Int. J. For. Res. 2010, 2010, 13.

30. Lohrey, R.E.; Kossuth, S.V. Pinus Elliottii Engelm. Silvics N. Am. 1990, 1, 338-347.

31. Smith, A.M.; Talhelm, A.F.; Johnson, D.M.; Sparks, A.M.; Kolden, C.A.; Yedinak, K.M.; Apostol, K.G.; Tinkham, W.T.; Abatzoglou, J.T.; Lutz, J.A. Effects of Fire Radiative Energy Density Dose on Pinus Contorta and Larix Occidentalis Seedling Physiology and Mortality. Int. J. Wildland Fire 2017, 26, 82-94. [CrossRef]

32. Hood, S.M.; Varner, J.M.; van Mantgem, P.; Cansler, C.A. Fire and Tree Death: Understanding and Improving Modeling of Fire-Induced Tree Mortality. Environ. Res. Lett. 2018, 13, 113004. [CrossRef]

33. Greene, T.A.; Shilling, C.L. Predicting Girdling Probability for Pine and Hardwood Saplings in Low-Intensity Backfires. For. Sci. 1987, 33, 1010-1021.

34. Brockway, D.G.; Outcalt, K.W. Gap-Phase Regeneration in Longleaf Pine Wiregrass Ecosystems. For. Ecol. Manag. 1998, 106, 125-139. [CrossRef]

35. Loudermilk, E.L.; Hiers, J.K.; O'Brien, J.J. The role of fuels for understanding fire behavior and fire effects. In Ecological Restoration and Management of Longleaf Pine Forests; CRC Press: Boca Raton, FL, USA, 2017; pp. 107-122. 
36. O’Brien, J.J.; Hiers, J.K.; Callaham Jr, M.A.; Mitchell, R.J.; Jack, S.B. Interactions among Overstory Structure, Seedling Life-History Traits, and Fire in Frequently Burned Neotropical Pine Forests. AMBIO A J. Human Environ. 2008, 37, 542-547. [CrossRef]

37. O’Brien, J.J.; Hiers, J.K.; Mitchell, R.J.; Varner, J.M.; Mordecai, K. Acute Physiological Stress and Mortality Following Fire in a Long-Unburned Longleaf Pine Ecosystem. Fire Ecol. 2010, 6, 1-12. [CrossRef]

38. Varner, J.M.; Putz, F.E.; O’Brien, J.J.; Hiers, J.K.; Mitchell, R.J.; Gordon, D.R. Post-Fire Tree Stress and Growth Following Smoldering Duff Fires. For. Ecol. Manag. 2009, 258, 2467-2474. [CrossRef]

39. Thaxton, J.M.; Platt, W.J. Small-scale Fuel Variation Alters Fire Intensity and Shrub Abundance in a Pine Savanna. Ecology 2006, 87, 1331-1337. [CrossRef]

40. Canham, C.D.; Denslow, J.S.; Platt, W.J.; Runkle, J.R.; Spies, T.A.; White, P.S. Light Regimes Beneath Closed Canopies and Tree-Fall Gaps in Temperate and Tropical Forests. Can. J. For. Res. 1990, 20, 620-631. [CrossRef]

41. Gray, A.N.; Spies, T.A.; Easter, M.J. Microclimatic and Soil Moisture Responses to Gap Formation in Coastal Douglas-Fir Forests. Can. J. For. Res. 2002, 32, 332-343. [CrossRef]

42. McGuire, J.P.; Mitchell, R.J.; Moser, E.B.; Pecot, S.D.; Gjerstad, D.H.; Hedman, C.W. Gaps in a Gappy Forest: Plant Resources, Longleaf Pine Regeneration, and Understory Response to Tree Removal in Longleaf Pine Savannas. Can. J. For. Res. 2001, 31, 765-778. [CrossRef]

43. Brockway, D.G.; Lewis, C.E. Long-Term Effects of Dormant-Season Prescribed Fire on Plant Community Diversity, Structure and Productivity in a Longleaf Pine Wiregrass Ecosystem. For. Ecol. Manag. 1997, 96, 167-183. [CrossRef]

44. Robertson, K.M.; Platt, W.J.; Faires, C.E. Patchy Fires Promote Regeneration of Longleaf Pine (Pinus Palustris Mill.) in Pine Savannas. Forests 2019, 10, 367. [CrossRef]

45. Crotteau, J.S.; Varner, J.M., III; Ritchie, M.W. Post-Fire Regeneration Across a Fire Severity Gradient in the Southern Cascades. For. Ecol. Manag. 2013, 287, 103-112. [CrossRef]

46. Jack, S.B.; Hiers, J.K.; Mitchell, R.J.; Gagnon, J.L. Fuel Loading and Fire Intensity-Effects on Longleaf Pine Seedling Survival. In Stanturf, Proceedings of the 14th Biennial Southern Silvicultural Research Conference. Gen. Tech. Rep. SRS-121; John, A., Ed.; US Department of Agriculture, Forest Service, Southern Research Station: Asheville, NC, USA, 2010; pp. 275-279.

47. Blackmarr, W.H. Moisture Content Influences Ignitability of Slash Pine Litter. Res. Note SE-173; US Department of Agriculture, Forest Service, Southeastern Forest Experiment Station: Asheville, NC, USA, 1972; p. 173.

48. Gagnon, J.L.; Jokela, E.J.; Moser, W.K.; Huber, D.A. Dynamics of Artificial Regeneration in Gaps within a Longleaf Pine Flatwoods Ecosystem. For. Ecol. Manag. 2003, 172, 133-144. [CrossRef]

49. Ansley, R.J.; Kramp, B.A.; Jones, D.L. Honey Mesquite (Prosopis Glandulosa) Seedling Responses to Seasonal Timing of Fire and Fireline Intensity. Rangeland Ecol. Manag. 2015, 68, 194-203. [CrossRef]

50. Wade, D.D. Thinning Young Loblolly Pine Stands with Fire. Int. J. Wildland Fire 1993, 3, 169-178. [CrossRef]

51. Bradstock, R.A.; Myerscough, P.J. The Survival and Population Response to Frequent Fires of Two Woody Resprouters Banksia Serrata and Isopogon Anemonifolius. Aust. J. Bot. 1988, 36, 415-431. [CrossRef]

52. Guldin, J.M. Uneven-aged silviculture of longleaf pine. In The Longleaf Pine Ecosystem; Springer: Berlin, Germany, 2007; pp. 217-249.

53. Sharma, A.; Bohn, K.; Jose, S.; Cropper, W.P. Converting Even-Aged Plantations to Uneven-Aged Stand Conditions: A Simulation Analysis of Silvicultural Regimes with Slash Pine (Pinus Elliottii Engelm.). For. Sci. 2014, 60, 893-906. [CrossRef]

54. Guldin, J.M.; Baker, J.B. Uneven-Aged Silviculture, Southern Style. J. For. 1998, 96, 22-26.

(C) 2020 by the authors. Licensee MDPI, Basel, Switzerland. This article is an open access article distributed under the terms and conditions of the Creative Commons Attribution (CC BY) license (http://creativecommons.org/licenses/by/4.0/). 